\title{
The Practice and Promise of Critical Information Literacy: Academic Librarians' Involvement in Critical Library Instruction
}

\section{Eamon C. Tewell}

\begin{abstract}
Critical information literacy is a way of thinking and teaching that examines the social construction and political dimensions of libraries and information, problematizing information's production and use so that library users may think critically about such forces. Being an educational approach that acknowledges and emboldens learners' agency, critical information literacy has much to offer librarians. Using a survey and follow-up interviews with thirteen librarians practicing critical information literacy, this paper illustrates some of the many ways that librarians incorporate this vital approach to teaching the complexities of information, as well as the potential advantages and difficulties of doing so.
\end{abstract}

Portions of this paper's findings have been included in "Putting Critical Information Literacy into Context: How and Why Librarians Adopt Critical Practices in Their Teaching," published by In the Library with the Lead Pipe.

\section{Introduction}

The educational activities of libraries are a vital component in pursuing their missions, whether conducted through the lending of collections free of charge, providing reference services in person and online, or developing instructional programs designed to teach library users how to find and evaluate information. In the United States, the concept of information literacy was first introduced in the 1970s, developed through the 1980s, and formalized and broadly adopted in the 1990s, particularly in academic libraries. Information literacy has widely served as a means to argue for the importance of librarians' roles as educators within an ever-changing information landscape. As information literacy has developed through the professional discourse and influential documents such as the American Library Association's Presidential Committee on Information Literacy Final Report (1989), the Association of College and Research Libraries' Information Literacy Competency Standards for Higher Education (2000), and the newly adopted Framework for Information Literacy for Higher Education (2016), until recently,

Eamon C. Tewell is Reference $\mathcal{E}$ Instruction Librarian at Long Island University, Brooklyn; e-mail: eamon.tewell@liu.edu. (C2018 Eamon C. Tewell, Attribution-NonCommercial (http://creativecommons. org/licenses/by-nc/4.0/) CC BY-NC. 
predominant conceptions of information literacy have been rooted in and expressed as mechanistic notions of information access and use. One collective response to information literacy's failure to address the social and political dimensions of information and education in libraries calls for a critical information literacy. This call to recognize the importance of social justice to libraries and librarians' work has gained visibility in the scholarly literature and profession as a whole since first making its appearance fifteen years ago. ${ }^{1}$

As a theory and practice, critical information literacy (critical IL) aims to understand how libraries participate in systems of oppression and find ways for librarians and students to act upon these systems. Critical IL applies critical theory and most often the aims of critical pedagogy to libraries, daring to imagine education as a site for generating social change. Critical information literacy is not limited to instruction; instead, it is a way of thinking about information literacy as a whole as it is expressed across various sites, from libraries' educational efforts to the professional and societal forces that shape these activities. Critical IL has much to offer librarians seeking to rethink not only their approach to instruction, but also the goals and actions of libraries more generally. As stated by Lua Gregory and Shana Higgins in Information Literacy and Social Justice: Radical Professional Praxis, critical information literacy "takes into consideration the social, political, economic, and corporate systems that have power and influence over information production, dissemination, access, and consumption." ${ }^{2}$

For the purposes of this study, critical information literacy is defined as an approach to education in library settings that strives to recognize education's potential for social change and empower learners to identify and act upon oppressive power structures. For this ambitious goal of fostering critical consciousness to take place, librarians must be equipped with an understanding of how to enact this change. This knowledge could include why people who feel critical information literacy is important identify it as such, and how these individuals incorporate the ideas of critical IL into their instructional practice. The development of librarians' critical understandings can occur in many ways, but the perceived theory-into-practice problem can be a common impediment, and that is an obstacle this paper wishes to address. ${ }^{3}$ Using an online questionnaire followed by interviews with thirteen academic librarians practicing critical information literacy, this research illustrates some of the possibilities for librarians to integrate this vital approach to teaching the complexities of information into their practice. In particular, this research explores how academic librarians make critical information literacy part of their classroom instruction and in what ways they find this to be a challenging or beneficial undertaking. The findings will in turn help other librarians to apply strategies for questioning dominant culture to their own work.

\section{Literature Review}

A number of important studies have critiqued information literacy and attempted to situate academic librarianship within larger paradigms shaping the ways its work is conceived of and carried out. The concept of information literacy, which is subject to cultural, geographical, and temporal contexts, has been examined as containing two inherently contradictory terms connoting control and democratic empowerment that may nonetheless be able to produce a creative tension for librarians willing to embrace this dualism, ${ }^{4}$ as a set of assumptions that not only lack the complexity needed to prepare learners for engaging with information but "present a hindrance to critical and transformative literacy practice, ${ }^{\prime 5}$ and as an attempt at legitimizing the profession in the face of technological changes that increased the ease of information access. ${ }^{6}$ In recent years, researchers have considered information literacy and libraries in relation to the imperatives of neoliberalism, a set of economic policies based upon the rule of 
the market that are increasingly applied to not just economics but all spheres of life, including education. ${ }^{7}$ These analyses of the aims of information literacy and the ideologies it is embedded within have done much to inform the ideas of critical information literacy, which itself critiques information literacy from a variety of perspectives.

The scholarly literature of critical information literacy as well as the broader literature of critical approaches to librarianship has increased considerably over the past decade, taking issue with the notion of libraries as ideologically neutral spaces, arguing for an understanding of information literacy that accounts for sociopolitical dynamics, and seeking ways to involve library users in the politics of information access and use. One researcher observes that, when she "started studying critical information literacy in 2009 , there was only a very small body of work to draw from." ${ }^{8}$ Many of the works of critical IL have been reviewed by Eamon Tewell and Beth McDonough. ${ }^{9}$ McDonough discerned practice implications from a body of 41 articles, book chapters, and dissertations addressing critical information literacy. The synthesis revealed several findings in relation to library instruction, including that the existing literature asks librarians to build upon students' existing understandings of information, to incorporate problemor question-based instruction, and to teach about all types of information in relation to its purposes and uses. McDonough found from her personal experiences that, "when I give students control, and begin with their experiences, they are much more willing to dialogue with me about information context and uses."10

One foundational work of critical information literacy is James Elmborg's 2006 essay, which followed a handful of articles discussing critical IL in libraries and played a large role in bringing attention to the concept. ${ }^{11}$ Elmborg draws upon the work of radical educator Paulo Freire in his consideration of critical IL as an approach to education that focuses on cultivating a critical consciousness in students, with the goal of facilitating students' abilities to "take control of their lives and their own learning to become active agents, asking and answering questions that matter to them and the world around them." ${ }^{12}$ Elmborg also considers the difficulties in defining critical IL, which is a useful starting point for exploring the term's implications. ${ }^{13}$ Early in its development, critical IL was also advocated for by Michele Holschuh Simmons, Troy Swanson, and John Doherty, each of whom address critical information literacy from various positions: adopting genre theory to help students adapt to disciplinary discourse while recognizing the contested nature of information, ${ }^{14}$ integrating a critical IL model into a first-year composition course at a community college, ${ }^{15}$ and using critical pedagogy to inform library instruction. ${ }^{16}$ A major cornerstone of the critical IL literature is the 2010 volume Critical Library Instruction: Theories and Methods, which features chapters exploring the intersections of critical pedagogy and library instruction and is a valuable resource for librarians interested in how critical information literacy might be attempted in the library classroom. ${ }^{17}$ The working definition of critical IL that this study adopts is based on the author's engagement with the critical IL literature described above; it is particularly influenced by key works of critical pedagogy by bell hooks, Paulo Freire, and Henry Giroux.

Librarianship informed by social justice and activism has a long tradition, highlighted recently by a number of books relating to critical and activist librarianship. ${ }^{18}$ Of particular interest to this discussion is Annie Downey's Critical Information Literacy: Foundations, Inspiration, and Ideas, wherein she interviews academic instruction librarians involved in critical IL work and draws upon her own experiences as an educator to examine how critical IL is practiced in a variety of settings, providing a wealth of insight. ${ }^{19}$ The literature of critical IL is becoming increasingly robust as its ideas are applied to credit-bearing courses,,$^{20}$ subject-specific library instruction, ${ }^{21}$ the political understandings of young adults, ${ }^{22}$ and its correlations with participatory information 
environments. ${ }^{23}$ A recent survey found that a number of librarians have familiarity with one of a number of critical theories, from postcolonialism to queer theory, and moreover, that many librarians are concerned with social justice issues as they relate to libraries. ${ }^{24}$ At the same time, examples of how critical IL is and can be practiced, as well as how different factors facilitate or inhibit critical IL work, are lacking from the existing literature. The gap between an increasing interest in critical IL and its application to one's work is what this research intends to address.

\section{Methodology}

The primary objective of this study is to investigate two research questions:

1. In what ways do academic librarians incorporate critical information literacy into their instruction?

2. What benefits and challenges do academic librarians identify in making critical information literacy part of their instruction?

As an exploratory study intended to gain understanding into the ways academic librarians practice critical information literacy in group instruction settings, this research uses an online questionnaire combined with in-depth interviews. A mixed-methods approach was adopted to combine two distinct approaches to the research questions in mutually informative ways, as well as to triangulate and improve the meaningful interpretation of the data. The questionnaire was designed to elicit brief responses from a larger number of librarians on how and why they make critical IL part of their instructional practice and recruit volunteers for potential in-depth interviews, while the interview questions were intended to elicit more detailed information regarding the benefits and challenges academic librarians encounter in this type of teaching. The survey responses informed the development of interview questions in that queries suited to in-depth discussion but difficult to describe in a brief survey format, such as first learning about the topic or theoretical and conceptual understandings, were created.

The population for this study is librarians employed by academic institutions who self-identify as incorporating critical IL into their classroom instruction. Because the research's purpose is to learn about the thoughts and actions of librarians practicing critical IL as opposed to obtaining a sample representative of the profession as a whole, the methodology uses convenience sampling, a nonprobability sampling technique. The research project was approved by the Long Island University Institutional Review Board, which protects the rights of human subjects in research studies affiliated with Long Island University.

The online questionnaire was distributed in November 2015 to the ili-1 and collib-1 e-mail listservs and through Twitter, remaining open for three weeks. The 12-item questionnaire was developed in SurveyMonkey and was open to "all individuals employed by an academic library, providing classroom instruction in some capacity at their library, and who identify as incorporating critical information literacy into their instruction." The survey concluded with the opportunity for interested respondents to be contacted for the possibility of participating in a follow-up interview. The full questionnaire is included as appendix A.

After the survey's conclusion, thirteen potential interviewees were contacted according to institution type, years of experience in the profession, and job responsibilities, to obtain data representing individuals from a variety of professional backgrounds and working environments. While not intended to necessarily be representative of the profession as a whole, these demographic characteristics were selected to uncover different types of experiences dependent upon one's setting. All thirteen respondents agreed to participate, and their preference for conducting the interview was obtained along with a brief demographic questionnaire and a form indicating their consent. 
Eight interviews took place asynchronously via e-mail over the course of January and February 2016, and five interviews between 30 and 75 minutes in duration took place via the video chat service Skype. The set of eight interview questions are included in appendix B.

In total, data collection took place from November 2015 to February 2016. The interviews conducted via Skype were recorded and transcribed by the author to build greater personal familiarity with the interviewees' responses. The interview transcripts and open-ended survey questions were subsequently exported to Microsoft Word and Excel for analysis. The survey and interview data were analyzed with a grounded theory approach using the constant comparative method. Survey and interview data were coded separately but with similar processes, beginning with open coding that used a combination of descriptive and in vivo coding, followed by memoing in separate documents, the identification of themes generated by each data collection method, and finally a comparison to determine shared themes. Due to the relatively small scale of the dataset, the aforementioned hand coding and a word search analysis in Microsoft Word and Excel were satisfactory in determining salient themes and findings for this primarily qualitative investigation. This was confirmed through the subsequent use of the qualitative data analysis program Dedoose for the interview transcripts, which did not reveal additional cogent or substantial themes.

\section{Participants}

The online questionnaire received 154 responses to the first five questions, which were closed-ended and gathered information regarding demographics. The responses summarizing participants' number of years of post-MLS experience working in libraries, type of academic institution where they are currently employed, and approximate student enrollment at their institution are summarized below. Though the survey asked for certain demographic information regarding participants, no correlations between participant demographics and one's critical information literacy practice were intended to be drawn. The data are provided so that the findings may be considered with participants' levels of professional experience and work settings in mind.

When asked "How many years have you worked in a library of any type after receiving your MLS or its equivalent," 58 participants indicated 0-4 years of experience (38\%), 41 with $5-9$ years (27\%), 29 with $10-14$ years (19\%), and 25 with 15 or more years of post-MLS experience working in a library $(16 \%)$. A majority of participants currently work in a university setting $(104 ; 67 \%)$, followed by a college $(29 ; 19 \%)$, community college $(12 ; 8 \%)$, or other type of academic institution $(9 ; 6 \%)$. The institution sizes in terms of enrollment were relatively evenly distributed, with six participants selecting "under 1,000" students (4\%), 41 participants with 1,000-4,999 students (27\%), 27 participants with 5,000-9,999 students (17\%), 38 respondents with 10,000-19,000 students (25\%), 18 with 20,000-29,999 students (12\%), 22 with 30,000 students or above (14\%), and two respondents who were unsure $(1 \%)$.

Question 6 asked whether respondents incorporate critical information literacy into their classroom instruction. Because the survey was advertised as and intended to gather the input of librarians currently practicing critical IL in their classroom instruction, the number of those responding that they do incorporate critical IL was accordingly high, at 70 percent (68). Other responses included "No" (15; 15\%), “Unsure" (12;12\%), and "Other" $(2 ; 2 \%)$, who specified that their practice of critical IL is in consultations with small groups of students and "it depends on the group." The remaining survey questions were open-ended and received between 60 and 73 responses each. These responses varied greatly and required analysis to determine broader themes; they are described in the Findings and Discussion section. 
Before in-depth interviews were conducted, the 13 interviewees were asked to complete a demographic questionnaire. The interviewees held a variety of job titles primarily related to instruction, outreach, or the department they primarily liaise with (such as "Education Librarian"). Three job titles indicated a departmental director or coordinator role, such as "Coordinator of Instruction." In terms of geography, four interviewees reside in the Pacific region, with two interviewees each in the East North Central, South Atlantic, and Mountain regions, and one interviewee each in the New England, West North Central, and East South Central regions. All but two of nine regions in the United States are represented by at least one interviewee.

Nine interview participants indicated that their gender is best identified as female, and four specified their gender as male. In terms of racial or ethnic heritage, one interviewee indicated their ethnicity as "East Asian or Asian American," three interviewees as "Latino or Hispanic American," and nine interviewees as "Non-Hispanic White or Euro-American." Regarding years of post-MLS experience working in a library, a majority of interviewees had 0-4 years (6) or 5-9 years of experience (5), while one interviewee indicated 10-14 years and one indicated 15 or more years. A variety of academic settings were well represented among interviewees, including university (6), college (4), community college (2), and a library jointly serving three institutions (1).

\section{Findings and Discussion}

A synthesis of the primary concepts that surfaced in both the survey and interviews reveal a number of themes within four different categories: Teaching Content, Teaching Methods, Challenges, and Benefits. Each of these categories, which follow below, emerged through being mentioned most frequently in the data. No significant subcategories or subthemes were identified. While some themes are documented in other studies and are identified as such, they were done so after being identified as opposed to prior to analysis.

\section{Teaching Content}

Librarians who self-identified as practicing critical information literacy in their classroom instruction contributed a wealth of examples through which they exercise this approach to teaching. After carefully reading these examples, considering their likely method and intent, and grouping them according to underlying ideas, five primary themes in terms of teaching critical information literacy topics emerged:

$\begin{array}{ll}\square & \text { Classification } \\ \square & \text { Search Examples } \\ \square & \text { Academic Conventions and Access } \\ \square & \text { Corporate Media } \\ \square & \text { Alternative Media }\end{array}$

These themes do not represent the range of possibilities for the content that is taught in critical IL instruction; instead, they serve simply as summaries of several ways that some academic librarians have found it useful to teach. A common difficulty for academic librarians who teach, and in particular those who wish to use a critically informed approach, is finding ways to address broader conceptions of information within the constraints of a brief standalone session. Moreover, for non-credit-bearing classes, the content a librarian addresses may be in large part determined by the suggestions of teaching faculty. This makes collaborative relationships with faculty a substantial factor in successfully incorporating critical methods. The following themes can serve as inspiration to the librarian seeking to make critical ideas more prominent in their classroom, whether it is a single session or a semester-long course.

The use of library classification systems as a text to be read is one way librarians are able to problematize the white hetero-patriarchal foundations of how knowledge 
is arranged in libraries while drawing attention to the constructed nature of these and other organizational schemes, as has been investigated since the 1970s. ${ }^{25}$ Teaching classification systems has the potential for showing students how tools such as subject headings contribute to the discovery or obfuscation of information while also reifying dominant ideologies and the oppressive representations this entails. Several participants used Library of Congress (LC) Classification as a starting point for discussions on information discovery, with one instance described here:

One example is a "close reading" of the main headings in the LC classification system, where students are asked what they notice and what they wonder as they look at the subject headings; this usually sparks interesting conversation about which "subject areas" seem to have more significance than others in the LC system, as well as how these subjects are labeled.

Another librarian developed a creative approach to discussing classification, which they found leads to the potential for much larger ideas to take root: "I've had students look at LC and Dewey classifications as 'anthropologists from the year 2815' and they try to hypothesize values the cultures that produced these ways of looking at information had - thereby opening up the idea that knowledge is conditional on time, place, and power." Teaching using classification as a point of departure can give librarians the ability to describe concrete examples with their students while allowing discussions to progress into larger ideas of how knowledge is organized in ways that reflect and maintain dominant belief systems.

Search examples were brought up consistently by participants, who made use of search terms related to racial justice, gender discrimination, and other issues likely to affect college students or transpiring in society at large. As described by Maria Accardi, search examples have the potential to act as a form of consciousness-raising by drawing attention to social issues and potentially making marginalized students feel that their struggles are recognized. ${ }^{26}$ One librarian explains the use of search examples:

I also make use of search terms that also have the effect of consciousness raising, like if it's a business class, or a session where they have some sort of careerexploration topic, using something about the gender wage gap or something like that as a search example can be interesting and powerful.

Other librarians mentioned using Freddie Gray or Black Lives Matter as search terms, while also noting why most library databases are unlikely to be an ideal source for obtaining the most recent information on rapidly developing topics. Part of participants' enthusiasm for search examples related to social justice issues may be due to the need for flexibility, considering course instructor demands and time constraints, as well as the ability to set the stage for more demanding pedagogical approaches. These examples can be used to bring important and timely questions to the fore of even the most inflexible one-shot session, as alluded to by one librarian: "Even in sometimes restrictive one-shots, I use example topics related to social justice issues."

One particularly rich area for discussing issues of power and control is located within academe itself. Librarians practicing critical IL are bringing to the surface a variety of academic conventions and issues related to information access. As one respondent notes, their classes may "look at the economic power structures that limit access to academic information (overpricing, password protection). We consider how peer review can lead to quality control or suppression of newer or more radical views." This troubling of not just ingrained academic conventions, but the economic basis for how 
traditional scholarly information is produced and often made available only to affiliates of higher education institutions through exorbitantly priced proprietary databases, is addressed by another librarian through the lens of information privilege: "I am really trying to focus my instruction/outreach on information privilege. This gets students to question what 'quality' is, how they cite and engage with privileged sources, and how/why marginalized voices might not be present in those conversations." For an introduction to libraries and information privilege, see Char Booth's excellent discussion. ${ }^{27}$ One librarian's aims were to not only problematize key components of academic information and its access through their teaching efforts, but to consider the entire enterprise of academe and scholarship:

One of my main focuses in teaching is to get students to understand how and why academia is structured the way it is, and to dispute the notion that this model is ideal for society. One way I teach towards this principle is by having students examine for whom academic scholarship is authored. One exercise I use is to have students compare different mediums (peer-review articles, newspapers, blogs) and ask guided questions to generate discussion around audience, authority and accessibility.

Being something that is used or encountered on a daily basis in many peoples' lives, a number of librarians developed activities and questions based on corporate media. While such topics may seem oversized for library instruction sessions that are frequently an hour to an hour and a half in length, one participant had success with interrogating popular media in this format: "I frequently design one-shot class sessions built around a few open-ended questions, and hope for students to drive the discussion. The topics have included bias in search algorithms and how editorial processes in popular media are designed to perpetuate the status quo rather than truly 'report the news.'" Participants designed their lesson plans most frequently in relation to Safiya Noble's extensive research on Google and other corporate search products ${ }^{28}$ as well as other researchers' important work on the discriminatory effects of search algorithms. ${ }^{29}$ Another librarian offered specific resources that they use to examine the profit structures underlying corporate media:

I encourage students to think about the profit structures behind the media. For example, with certain first-year students, I will show them the site "Who Owns the Media" to talk about bias and monopolies. For another example, in some political science or policy classes, we investigate www.opensecrets.org, to see which organizations lobby on behalf of legislation.

Just as some librarians found that focusing on corporate media processes and motives was a productive way to talk about information literacy with their students, others were interested in focusing on alternative and counterculture media. Actively incorporating alternative media into one's instruction is likely to have the effect of information being taught in a broader sense than that which is found within a library's holdings and subscriptions. Centering alternative media is one way of introducing questions of who gets to publish, as well as a means of bringing in marginalized perspectives while showing students that their own voices could also be heard through various channels. One librarian used zines to accomplish this: "I do a lot of teaching with zines, focusing on self-publishing and the amplification of frequently marginalized voices - this always includes opportunities for students to make and share their own work." Accompanying this shift toward discussing counterculture resources is the discussion of mechanisms 
within different types of publishing. The teaching of various types of information, not just academic, and not making value judgments based on where information is retrieved, is reflected in McDonough's synthesis of the critical IL literature. ${ }^{30}$

Fewer librarians addressed credit-bearing courses than those teaching one-shot sessions, but these extended instructional modes offer opportunities for powerful ideas to be explored in much more depth and detail. A model very much aligned with the critical pedagogy methods of problem-posing and taking action in one's community was described by one participant: "In my credit course, students choose a topic related to an issue facing their community (self defined) and write an advocacy letter suggesting a course of action based on their research. I also have them participate in a class action research project (develop a topic and survey question together)." The uses of studentdirected learning, community advocacy, and action research are all promising modes of critical pedagogy in higher education settings. One interviewee addresses issues of whiteness in academe and source credibility by examining their own institution:

In a credit bearing course, I showed the video "Why is my curriculum white?" then challenged students to find demographic information on our university's student population and faculty. After discussing how they found this and examining which source seemed more credible, I asked them to consider why there is such a disparity (35\% African American students, but close to $90 \%$ of faculty are white) and how that affects what information \& perspectives get published in books and journal articles.

While many librarians who participated in this study naturally felt a degree of comfort with these teaching approaches and developing new instructional ideas, a number of survey respondents expressed difficulty with incorporating critical IL into their instructional practice, or that they have found only small ways to do it due to faculty expectations to have them show the library's resources. Importantly, critical approaches to libraries are not limited to teaching, and several participants noted how critical pedagogy informs their work in reference services or collection development. As one individual underscored: "[C]ritical theory and critical pedagogy inform all aspects of how I do my work in addition to my work in the classroom. It underpins my one-onone work with students, training for reference assistants, collection development, etc."

Finally, survey participants related a number of interesting things they would like to investigate in their instruction. These topics included race ("I would love to get students thinking more about racial disparity among faculty in higher education and how that affects who creates knowledge within the disciplines"), disciplinary integration ("I would also like to address how publishing and knowledge creation legitimates disciplines...I briefly touched on this when my first-year students discussed Chicano/a studies, but I would like to get into it more"), using resources other than the library ("I love the idea of spending time focusing on [W]ikipedia in sessions"), and open access ("I would like to bring more about the Open Access movement and its ideological foundations into my instruction").

\section{Teaching Methods}

The content of critical information literacy instruction and its methods are necessarily intertwined, and so the topics addressed above are important to consider in light of the methods used to explore them. Key teaching methods that librarians who practice critical IL report as using most often include:

$\square \quad$ Discussion and Dialogue

Group Work 
$\square \quad$ Skipping the Database Demonstration

$\square \quad$ Reflection

Problem-Posing

Each method acts as a way to eschew the deficit model of student learning that permeates education, aiming to position students as active mediators in the interpretation and creation of information. The recognition of students' lived experiences, existing understandings of information, and potential of their contributions to their classmates' and the teacher's learning are important foundations of these methods.

Creating opportunities for dialogue and discussion was central to the instructional practice of many study participants. bell hooks describes the use of dialogue in the critical classroom as such: "To engage in dialogue is one of the simplest ways we can begin as teachers, scholars and critical thinkers to cross boundaries, the barriers that may or may not be erected by race, gender, class, professional standing, and a host of other differences." ${ }^{31}$ One librarian offered an encapsulation of their dialogic approach:

I lecture as little as possible and like to have students work together, present findings/ideas/reactions/etc. to the class, and then engage in a whole-group discussion. Again, I attempt to engage students in material that (a) they can relate to; and (b) will get them thinking. This ranges from group work exploring a variety of sources surrounding the murder of Trayvon Martin to acting out a scholarly debate on the coming out process.

While many librarians not using an intentional critical information literacy approach make discussions part of their instruction, the difference lies in the intentionality and social justice aims of critical librarians' classroom discussions, which are often carefully framed around issues of power, privilege, and inequality. "While learner-centered approaches to teaching," such as discussion, "are concerned with what the learner ends up learning," Accardi states, critical and feminist approaches care about "what the learner does with the knowledge gained in and outside the classroom. ${ }^{\prime \prime 2}$ The popularity of discussion and dialogue as a method for critical librarians is reflected in Downey's study, where half of the 19 interviewees used it as the primary device to teach critical IL concepts. ${ }^{33}$

Sometimes in tandem with discussion, participants indicated the frequent use of group work in their classrooms. For one librarian, group work functioned as a mechanism to establish an understanding of students' aims and interests as well as a means to have students share their ideas more openly:

It is difficult to establish trust in a one-shot lesson-I need student input to understand where they're at, what they are working towards, what gets them engaged. With group work, they are feeding off of an energy or a mood that's already been established. I find group work then allows students to be more open in their ideas and more open to error.

Both survey respondents and interviewees identified the facilitation of conversations between students and between the students and instructor as important to their teaching. With group work in particular, students collaborate and use one another's knowledge to complete an assignment or activity. When introduced with purpose and planning, small groups also have the possibility to shift the control and focus from the instructor to the students, thereby potentially destabilizing this traditional hierarchy and the teacher-dominated content that so often defines what students are encouraged to know. 
The demonstration of how to access and search library databases, often a staple of information literacy instruction, was avoided by critical librarians in favor of methods that promote student contributions and agency. One interviewee described a particularly creative approach to the topic of representation in scholarly publishing:

Instead of simply demo-ing a database, I facilitated a role-playing activity in which [students] assumed the roles of scholars, and we then had a discussion about who gets to be a scholar and thus who has a voice in the literature. This was all new to them, and I think they were able to both understand what "the literature" is and problematize academia in ways they hadn't before.

In trying instructional methods different from lecturing and demonstrating the access and retrieval of information from library resources, critical librarians found it useful to go beyond this familiar mode of teaching and have discussions about the resources they would otherwise simply explain to students. McDonough's investigation of the critical information literacy literature similarly found that the authors advocate for centering student experiences in library instruction, something quite difficult to achieve through the demonstration of resources. ${ }^{34}$ Furthermore, students have important contributions to make in respect to information access and use. As Pamela Martin notes, it is quite likely that "our patrons have been searching online for years, so to assume they know nothing about information seeking is offensive and naïve." ${ }^{35}$

An important component of critical IL practitioners' work is the use of reflection. Reflection was mentioned both in terms of in-classroom practice and providing oneself time before or after teaching to reflect on one's pedagogy. One librarian describes their integration of reflection as such:

Allowing students time to reflect or posing questions that ask them to consider how/if the lesson is meaningful to them is [an] important part of the classroom experience for me. Ideally, it adds a small jolt to their experience and communicates to students that I'm here for them, that I want to be a useful and purposeful addition to their classroom, not some intruder with my own agenda.

Reflection and dialogue can be particularly powerful teaching methods when combined, as critical pedagogy or critical IL is not something that can be imported wholesale into one's own context without reshaping it. As Downey states, "Teachers involved in the project of remaking critical pedagogy - or information literacy - for their context should consider the students they are working with and then remake their pedagogy with those students through dialogue and reflection." ${ }^{36}$ This project of remaking critical approaches to teaching for one's own setting is considered by Joshua Beatty in the application of Paulo Freire's methods to first-world librarianship. ${ }^{37}$ Additionally, Emily Drabinski offers the ancient Greek notion of qualitative time, kairos, as a way to understand and focus upon the contextually embedded nature of teaching while directing attention away from "universal" standards developed by professional bodies. ${ }^{38}$

A fifth critical teaching method employed by academic librarians is that of problemposing. Researchers have previously suggested that critical IL take a problem-based approach, due to its modeling of "constructing meaning through active engagement with the ideas and asking questions surrounding the information itself," ${ }^{39}$ and its parallels with Freire's problem-posing method that involves the development of knowledge through dialogue on issues important to learners. ${ }^{40}$ Problem-posing is often applied by librarians through centering an entire class session upon the examination of a real problem that is of concern and interest to the students. One interviewee has done exactly 
this in class, asking faculty to help think of a problem the class could investigate: "I have started asking the faculty to help me think of a problem the class could work on together, which I think is the best thing to have happened for my teaching in a long time." For this librarian, a small demand of faculty has led to large gains in authentic student involvement and learning. Given that the development of critical consciousness in relation to information cannot happen solely through a librarian's efforts, this participation of faculty in the design of meaningful classes appears to be both rewarding and necessary, pointing to the importance of strong collaborative relationships.

\section{Challenges}

Because a great deal of one's work is determined by institutional expectations, professional norms, and other demands and considerations, these boundaries very much shape how librarians conceive of and are or are not able to realize their critical IL practice. For that reason, the possibilities of critical library instruction are important to consider in relation to the challenges faced. As Ian Beilin observes, "critical librarianship has proposed that information literacy take up the methods and praxis of critical pedagogy to transform library instruction. But this must be negotiated within the specific local contexts of the contemporary neoliberal academy." ${ }^{41}$ Within these contexts, what challenges do critical IL practitioners contend with? The primary barriers faced in teaching critical IL include:

$\begin{array}{ll}\square & \text { Time } \\ \square & \text { The One-Shot Model } \\ \square & \text { Student Expectations } \\ \square & \text { Faculty Expectations } \\ \square & \text { Teaching the Basics } \\ \square & \text { Institutional Roadblocks }\end{array}$

Each of these challenges is explored in further detail below. Downey found three of these themes present in her interviews with critical librarians, including a lack of time, mismatches between critical teaching methods and the structure of institutionally defined library instruction, and lack of alignment between librarians' goals and professors' or classes' goals. ${ }^{42}$

The issue of time, whether in the classroom or in preparing for teaching, is a major consideration. Five interviewees specifically mentioned time or the lack thereof. The issue of scalability with a preparation-intensive teaching approach like critical IL is mentioned by one librarian: "Another concern, primarily for the larger-scale projects, is the amount of time and preparation; I certainly couldn't engage at that depth with more than a handful of the 30+ instructional sessions I do per semester." Another participant views time, the one-shot format, and connecting with students as being related challenges: “Time is a problem. It's hard to dive deeply [into] any issue in 50 minutes. The lack of rapport with students can also be an obstacle. They expect me to talk about library resources and don't always understand what I'm attempting." One individual insightfully recognizes the barrier they face is not entirely that of time, but of how time with students is arranged and determined by other factors: "I'm tempted to say that I don't have sufficient time with students, which is at least partly true. But beyond strictly a sufficient amount of time, the structure of my time with students and what kind of contact feels negotiable with disciplinary faculty is really more the issue."

Closely related to the challenge of time are the constraints imposed by the oneshot session, temporal and otherwise. Six interviewees and nearly half of the survey respondents mentioned this barrier. One participant memorably likens one-shot instruction sessions to a trash receptacle: "Well, one-shots are such a garbage can, really. Even the most sophisticated pedagogy is really, really limited in that format." 
Others expressed frustration with the lack of intentionality behind library instruction opportunities, stating that their "main challenges center around the way in which librarians typically are afforded the opportunity to provide instruction: whether at the reference desk or in the classroom, the majority of instruction opportunities are ad hoc and one-off." This in turn leads to the difficulty of knowing if one's teaching efforts have made an impact, described by an interviewee: "Given the one-shot model, it's not always possible to see the long-term impact of your work. If you don't personally witness conscientização [critical consciousness] in a student, then how do you know it's working?" The constraints within a one-shot session, then, presented significant difficulties for librarians seeking to delve deeply into information structures as well as work more intently with students.

Student expectations were another challenge encountered by critical instruction librarians. "Quite often, this approach to instruction is wildly different from what students encounter in other classes," one participant replied, "to the point that they don't know how to react when they're asked 'What's your opinion about this? OK, why do you think that?'” Another librarian reiterated these comments, connecting student expectations with the limited space of the one-shot session: "They're used to recitation, not critical discussion. This problem is exacerbated when relying on oneshots, because there's no chance to build a rapport and reframe student expectations." Participants pointed out that the problem is not with students themselves, but an educational system that tells them their viewpoint is not valued and that passivity is the "easiest" way to get through a class. Noting student discomfort with pedagogical methods that do not rely on lecturing or other forms of teaching that are immediately recognizable to students, one respondent observed, "Students can be uncomfortable or view the librarian as 'not teaching' when asked to draw on their own experiences and knowledge." Another issue is that of questioning academe, a balancing act approached with caution by one librarian: "I feel as though I am walking on thin-ice when asking students to challenge the inner-workings of academia."

As with students, course instructors and faculty are likely to have their own set of expectations regarding library instruction, making it imperative that if critical library practice is to flourish, changing these expectations and working collaboratively with faculty is required. One interviewee identified a lack of faculty understanding concerning the scope of librarians' goals in their teaching: "Faculty don't know that librarians actually think about these things and have a pedagogy and theory that drive our work. They think we just show databases and that is the extent of our value. Changing that perception is very hard and often demeaning." Faculty requests for instruction often characterize this misunderstanding, with these requests frequently being "of the 'just teach the databases' variety." Embedded in this asymmetrical power distribution between librarians and teaching faculty is not just librarians' status as instructional "support," but other factors such as seniority and tenure. "The regular course instructor can also be a big challenge," one respondent explained. "It is not always clear what their attitudes/approach to pedagogy are and as a young, tenuretrack librarian I often feel like I need to 'play it safe.'” This becomes even more of a concern when librarians with marginalized identities face these power dynamics and must question whether the risks posed by critical instruction are worth the potential advantages. Another librarian found the redefinition of faculty expectations to be key for a critical IL approach to take place: "Many instructors, and some of my colleagues, assume that library instruction equals a demonstration of the catalog or of a specific database, so redefining expectations is essential for incorporating critical information literacy." While this is undoubtedly a large undertaking, the following section on the benefits of critical IL will present examples of how librarians have approached this task. 
Institutional constraints were on the minds of many critical librarians, but one prominent difficulty was found in terms of pedagogy. This challenge is that of assisting students in meeting the specific needs of their academic work and course assignments while also teaching the sociopolitical dimensions of information more broadly. One interviewee voiced concern over addressing the needs of all students through their pedagogical approach:

It's difficult to both help students grasp the basics (e.g. how to work through the call number to find a specific book) and branch out into a more critical approach to research. It's helpful to know the rules before breaking them.... I worry that sometimes the critical approach may actually do a disservice to our first-gen students, if emphasizing the critical side displaces opportunities to practice the basics.

A different apprehension regarding student preparation for questioning dominant ideologies was expressed in relation to students becoming accustomed to academe: "Making students too critical too soon is like removing the floor from beneath them. As freshmen, they might not be ready to become disillusioned or to learn to break the rules about authority, bias, audience, purpose, or other evaluative categories." An important point here is that as in any classroom, there are multiple demands to consider, and striking a balance between everyday and aspirational goals is ideal. Heidi Jacobs articulates this balance as such: "What I am suggesting is that the dialogues we have surrounding information literacy instruction strive to find a balance in the daily and the visionary, the local and the global, the practices and the theories, the ideal and the possible." ${ }^{43}$ This challenge of teaching the basics while remaining true to critical methods might be achieved by better understanding our students. To "encourage alternative definitions of success while at the same time ensure success in the existing system," Beilin suggests, "librarians should ask themselves, 'Who is the student? What do you know about the student?' This should be one of the first things to understand before this complicated balancing act can succeed." ${ }^{44}$

Institutional roadblocks and/or a lack of support within one's institution were identified by other respondents as the biggest challenges faced in their practice of critical IL instruction. As stated by one participant, sometimes those in more powerful positions may be uninterested in or actively oppose critical teaching: "My biggest challenge was supervisors and professors - when the higher-ups are against it, there's little you can do to change." Institutional culture and affiliations present another set of issues: "One of the particular problems in my context is that as a religious institution we attract students who are not used to challenging power structures but rather accepting them as divinely produced." Apart from an institution itself, larger issues of assessment demands and the corporatization of higher education present particularly sizable barriers to critical practice. An interviewee notes the ways they comply with rigid assessment procedures while also performing the assessments that are more personally meaningful:

Assessment culture privileges ways of teaching and learning that are quantifiable. I can't put "changed lives and enacted social change" on a rubric, but I am pressured to report student learning findings in ways that are rubric-able. So I do the rubric, but I still do my own qualitative assessment alongside the stuff I'm required to report.

Two interviewees specifically mentioned the corporatization of education as impeding the development of their critical practices. Being involved in a theory and practice that 
opposes trends of the neoliberal university while often being embedded within these institutions presents an array of challenges as well as opportunities. It is imperative that librarians aiming to foster social change within their classes, libraries, and institutions at large come to know the structures that they operate within, and, as Karen Nicholson states, "find productive ways to talk about our role in preparing students for work while continuing to advocate for education and libraries as public goods" within the neoliberal regime. ${ }^{45}$ In addition to and inseparable from external challenges, it is clear that critical information literacy demands a great deal from librarians. As Jessica Critten underscores, critical IL requires professional autonomy to develop curriculum, time and access to enrich one's knowledge base, emotional labor to engage in demanding work, and a level of comfort in not receiving measurable, immediate results. ${ }^{46}$

\section{Benefits}

Despite the many difficulties that practitioners of critical information literacy identified, they choose to continue their efforts in part because of the benefits critical teaching affords them and the people impacted by their work. Five themes arose from participants' remarks and comments on the advantages of making critical IL part of their classroom instruction:

$\begin{array}{cl}\square & \text { Increased Engagement } \\ \square & \text { Meaningful for Students } \\ \square & \text { Meaningful for Librarians } \\ \square & \text { Connecting with Faculty } \\ \square & \text { Creating Community }\end{array}$

When considered as a whole, these themes denote an educational practice that has the potential for a higher degree of meaningfulness and engagement for students and librarians alike, while also leading to opportunities to connect with faculty and develop a stronger sense of community inside and outside the classroom.

Student engagement in librarian-led classes was cited frequently by participants as one of the benefits of a critical IL approach. This engagement was identified as being the cause of investigating topics of interest to students, of looking at real-world problems, and using teaching strategies that involve students, whether discussions, small-group work, presenting for their classmates, or other participatory methods. "I definitely get far more engagement than I did using non-critical pedagogical methods," one survey respondent remarks, sensing that, "students seem to end the class feeling more empowered to discuss research." An interviewee identified the many advantages of developing an authentic connection with students, which is facilitated through the use of critical information literacy: "It is a way to have an authentic connection with students, which I think assists in learning but certainly keeps students more engaged in the classroom. It is also a way for me to enact my values in my work, which keeps *me* engaged, and prevents burnout." The theme of engagement among students was a major one, mentioned specifically by 40 survey respondents and seven interviewees.

While student engagement is important and plays a role in learning, librarians identified employing critical perspectives in their instruction as also leading to more meaningful learning experiences for students. This meaningfulness was often referred to in terms of relevance and the "real world," as one librarian explains the benefits of a critical approach to library instruction: "Describing the power structures gives teaching a real-world relevance. It helps break the mold of 'the library is for books and journals' and allows students to see how IL concepts will apply in their life beyond college." One interviewee credits the divergence from a "sterile, linear approach to research" as leading to an increased sense of meaningfulness among learners: 
I am generally impressed by the discussions students have and the work they produce when I'm using a critical IL approach. Often it seems like students are so accustomed to taking a sterile, linear approach to research that they are surprised and relieved to be able to talk about it in a more nuanced way. For example, I think that most undergraduates feel alienated from scholarly conversations, but they don't often have a way to express and critique that frustration in a classroom environment.

hooks similarly recognizes the importance of meaningfulness to students, noting that "all students, not just those from marginalized groups, seem more eager to enter energetically into classroom discussion when they perceive it as pertaining directly to them." ${ }^{47}$ An interviewee perceives the interconnectedness between meaningfulness and student engagement, while at the same time noting that the long-term goals of critical teaching librarians are unlikely to be realized within a time frame as short as a semester: "I think it is more meaningful, and therefore more engaging. I think it is important to identify oppressive power structures-realizing ... there is the first step toward acting upon them. These are new ideas for many of my students, so I see myself as sowing seeds that may take longer than one semester to sprout." A dedication to involving students in questions of information and social justice, despite the unlikelihood of immediately seeing the effects, is central to critical librarians' teaching.

A related finding is that incorporating critical information literacy into one's teaching is also meaningful for librarians. One participant replies, "Selfishly, it invigorates me! I get to discuss things that are really interesting and meaningful to me, to break the mold of traditional library instruction content, and it seems to really engage students in ways I haven't seen before." If, as observed by respondents, the discussion of societal issues in the library classroom positively impacts student engagement and the meaningfulness of what is taught, the use of critical IL approaches equally freed respondents to teach about topics in ways meaningful to them. For one librarian, critical IL informs "how I approach and interact with students. In a bunch of ways reading and thinking about critical information approaches causes me to feel and act much freer in the classroom." An interviewee credits critical IL with not only making the work more meaningful, but with potentially keeping that librarian in the profession:

I don't think I'd still be doing what I'm doing if I hadn't learned or figured out that I could use critical information literacy in the classroom, because I would be so burned out and bored by point-here-click-here teaching. Not that I don't experience burnout at all, of course ... but I guess very early on in my career I had this sense that there has to be something more than this. I knew I was capable of so much more than teaching students to click on stuff and type words in a box!

The sentiment that "there has to be something more than this" was reflected by several interviewees in regard to their library work prior to learning about and developing a critical approach. For librarians who discovered critical IL, it appears they have found what that "something more" is and have continued on a path of using theory, practice, and reflection to help inform what they do in their work and how they do it.

Many participants in this study indicated the connections they have made with faculty and course instructors as a result of ideas related to critical pedagogy, critical theory, and/or critical information literacy to be a major benefit. "As I've been exploring CIL I've been continually amazed at how many other faculty on campus come from a critical or social justice background!" one interviewee explained, continuing, "CIL helps me make immediate and deep connections with the faculty I relate to and with whom I work ... 
as I teach IL sessions." These shared backgrounds and interests were described by a number of librarians who had since used their connections to further collaborate with faculty, whether in the redesign of course assignments or tailoring their instruction more closely to the needs of specific courses. Another librarian makes the intriguing point that while "information literacy" as a goal is accepted by faculty to different degrees, developing a sense of criticality among learners is more important and integrates easily with various disciplines, perhaps due to the nonfixed meaning of "critical":

Our disciplinary faculty members vary widely in their acceptance of the term "information literacy," but across the board, they're interested in their students becoming more critical researchers. Depending on the discipline and the individual faculty member, the specific interpretation of "critical" varies widely. Yet since exploring various librarians' writings on critical information literacy, I've found that this type of approach to instruction meshes more easily with that of my disciplinary faculty colleagues.

One participant described this connection between critical IL and the theoretical bases of faculty, and how that allows him to bring more of his own and others' interests and identities to their learning:

I feel that I make connections with other teaching faculty when I utilize CIL as well-it connects to their theoretical bases. I feel much more like a whole or holistic teacher or participant in my library classes when I'm bringing more of me into the classroom, and thereby inviting others to do the same.

Critical information literacy was described as an approach that encourages connections with students and faculty and brings meaning to librarians' work and students' learning. A final related theme that emerged is that of creating community. This theme is best summarized by this participant's words:

I find that the best library instruction sessions are where the students are given a lot of agency ... their ideas, the formation of community (as brief as it is within a classroom), and their shared dialogues are inspiring. These are the moments that education really becomes inclusive and students are allowed to be thinking, sharing beings.

One librarian simply, but importantly, found that they were being more open and honest with the students they work with: "It's hard to describe the benefits, but I believe I am being more honest and open with the students and feel that they respond positively to this in the classroom." Another participant echoed this openness and its rewards:

My interactions with students are much more human than when I lectured or demonstrated databases. In the best case scenario, we talk about who we are and how systems work, rather than trying to get to a predefined outcome involving a particular library resource. We talk about bigger issues and how they might change things, which is very rewarding [to me] as a teacher.

\section{Questioning Critical Information Literacy}

Overall, participants were extremely enthusiastic about critical IL and eager to share their experiences. The questionnaire also attracted several respondents who questioned the validity of this approach to teaching on various grounds. One librarian suggested 
an additional survey question: "Is this really the role of libraries, library instruction, or information literacy? This is an important question which probably should have been included on your survey" -implying that they would provide a negative response to the hypothetical question posed. Another respondent indicated that they would require additional information on critical IL's "efficacy" or "value" before being persuaded to adopt it: "I have yet to be convinced of either the efficacy or the value of "critical information literacy' instruction as opposed to information literacy education." Such proof of value or efficacy is unlikely to be forthcoming, however, as critical IL practitioners frequently view the measurement of "efficacy," "value," and other concepts with skepticism that they might measure what they claim to, much less that they can capture what matters in teaching and learning. A third respondent provided a spirited questioning of the premises of critical IL, and whether librarians should involve themselves in the quest for equality and justice:

It's not our role to promote social change or empower learners to identify and act upon oppressive power structures; our learners * may* do that with what they learn from us about information literacy and critical thinking, but in our roles as academic librarians in publicly funded institutions we are not to direct them to any specific ends except to learn information literacy concepts and how to apply those concepts to their tasks at university to succeed at particular assignments in particular classes in particular programs. We ${ }^{*}$ may ${ }^{*}$ be called on to teach them how to apply information literacy and critical thinking to identify and act upon oppressive power structures, and if so we *may* do choose to do so.... In our role as academic librarians, we are not paid to subscribe to some abstraction about oppressive power structures or to apply our skill sets to an ambiguous and amorphous idea of "social change." Information literacy and critical thinking skills are the oxygen in the fire of social changes of many kinds; if we decide to start telling the fire where and how and what to burn, we risk burning down the objective stance we have built up over at least the last century.

This respondent offered an interesting perspective on several issues. First is the idea that librarians have no more to offer than to serve as a guide to locating information for class assignments. This is unfortunate, as librarians in fact have a great deal to contribute to their campuses and students' lives, regardless of whether they are "called on" by an administrator, director, or faculty member to teach in a specific manner. It appears that the respondent is particularly concerned with being an agent "in the fire of social changes." No such "objective stance" exists, and the fires of social change continue to burn with or without librarians' active involvement. The question is whether librarians will fight inequalities alongside the rest of the world, or whether we wish to pretend that we can maintain neutrality in the midst of social issues that affect us, our patrons, and our planet, thus maintaining a status quo that we may think does not directly affect us, but does irreparable harm to us and the very people we work with.

\section{Conclusion}

Academic librarians who identify as taking critical IL approaches in their teaching do so in a number of ways, whether through the application of methods that aim to destabilize established hierarchies in the classroom and foster meaningful discussion and dialogue between students, the integration of topics that interrogate systems of oppression both within academe and out, or a combination of both. As this research demonstrates, there is no right way to teach using a critical information literacy ap- 
proach. What underlies the varied pedagogies described above is that the librarians try to teach "from the heart," to use one respondent's words. As long as one's intent is to challenge forms of oppression and to do so with the guidance of students, one may be thought to be teaching critically. As long as one holds close the aspiration of education as the practice of freedom, one may be thought to be involved in the project of emancipatory education. ${ }^{48}$

This study serves as an exploration of one aspect of critical IL: classroom instruction in academic libraries. There are a number of other avenues that librarians in a variety of settings are exploring in relation to critical librarianship, from collection development to library technology. Moreover, critical IL is not limited to the practice of librarianship, and the questioning of the premises of information literacy as well as education in libraries is ongoing. This important work of being critical of one's profession is done out of a love for libraries and librarianship and can ultimately serve to align libraries with the ideals of social responsibility and the public good they often invoke.

Because this study took a necessarily limited view of critical IL, future research might examine the many other areas of critical librarianship as theorized and practiced in libraries of different types. Theoretical treatments of librarianship and the constructs that guide it would be welcome additions to the literature, along with descriptions of the praxis of librarianship and how critical librarians' efforts are negotiated within larger structures. One issue of importance that this study did not adequately address is how critical librarians' identities impact their work, especially how one's ethnic and gender identities may contribute to their professional values and priorities, and the challenges faced by librarians with marginalized identities in practicing critical librarianship that challenges the status quo.

Another area of research could be the extent to which libraries are collaborating with various groups, such as student, staff, or community organizations, as a way to further shared missions of social responsibility and work toward causes of antiracism, antisexism, antihomophobia, and the elimination of other axes of oppression, described by hooks as the white-supremacist-capitalist-patriarchy. ${ }^{49}$ One interesting consideration relevant to the study at hand would be to examine the overlap of librarians who do not identify with critical IL and use similar content and methods, or have similar aims. As one respondent observes: "I think many librarians have been teaching critical information literacy concepts and content for years, without using the phrase," and this is both a limitation to this research as well as an intriguing subject to explore further.

As a gesture to librarians interested in critical IL instruction but uncertain where to start, this article concludes with several participants' recommendations. The survey respondents were asked what advice they would give to academic librarians interested in making critical IL part of their instructional practice but unsure of how to do so. While a number of people stated that they would like some advice themselves, many useful ideas were shared. These ideas are presented separately from the findings because they are intended specifically as considerations for librarians interested in beginning or furthering their critical practice. These suggestions fell into several themes: Seek Out People with Similar Interests; Start Small; Read and Reflect; and Pedagogical Advice.

Many librarians practicing critical IL recommended establishing connections with others who have related interests. Collaboration with faculty and other members of one's campus was recommended by several respondents, reflected by the comments, "Find allies on your campus and work with them and support their creative activity," and "Find a faculty member whose assignments parallel the concepts you want to teach and cultivate a close relationship with that person." In addition to facilitating relationships with people at one's institution who may have similar aims, librarians pursuing a critical practice may want to seek out other librarians involved in this approach. "There's 
a growing number of practitioners who are sharing accessible and thoughtful examples of how they incorporate critical pedagogy into their classroom," one librarian explains, and so "seek those out and start conversations." Critical librarians were described as "excessively helpful" and practical approaches to critical information literacy are growing rapidly, most notably with the publication of the two-volume Critical Library Pedagogy Handbook. ${ }^{50}$ One participant noted the importance of developing a supportive network wherever one is able: "One of the most important things is to have a support network from practicing critical IL. It's great if this is within your own library, but it's also important to find subject faculty allies. \#critlib is also great for a wider network." \#critlib refers to the Twitter hashtag short for "critical librarianship," where facilitated chats occur and resources are shared. ${ }^{51}$ \#critlib was mentioned by six interviewees, indicating the importance of this informal network for library workers interested in broadly defined critical approaches. Three interviewees were active in or members of the Progressive Librarians Guild, an organization founded in 1990, and the American Library Association's Social Responsibilities Round Table.

One need not reinvent their instruction from scratch, as it was recommended to start small when trying critical IL in the classroom. Minor changes can lead to the confidence necessary to use more challenging methods:

Start with something small-I started with 'jazzing' up the keywords examples I used and that led to really meaningful conversations with students which gave me confidence to explore other critical information literacy practices.

Another librarian relates the use of academe as a starting point for meaningful discussions:

It's ok to start slow. If you're not ready to jump in to dismantling oppressive power structures like racism and sexism, start by breaking down the rationale behind academic power structures and practices. For example, why does anyone care about citing sources? Most students have only been told not to plagiarize, but all of their explanations for 'why?' involve potential penalties.

To apply critical IL or new pedagogies, one need not be an expert. As Schroeder notes in his book of interviews, some critical librarians "have never been exposed to a critical theory, yet they continually ask many of the same critical questions, about power, privilege, and inclusion or exclusion, on a daily basis in regards to their patrons and libraries." ${ }^{52}$ One participant offers encouraging words for those unsure of their footing:

You don't need to be an "expert" in critical theory to try new approaches. The mere act of reflecting on what you're doing, and why, is the foundation of critical pedagogy. Praxis can only come from thinking about what you're doing and trying new things. They won't always work, and that's OK! Don't let the assessment regime get you down - there's still room for mistakes in the classroom.

Reading and reflecting was endorsed by a number of librarians practicing critical information literacy, particularly as it relates to praxis and informing one's actions. In Critical Journeys, Jacobs describes the importance of giving ourselves "permission to pause" and take time to "stop, think, reflect, discuss, share, listen and let our collective minds wander regarding the questions that are most pressing for us." ${ }^{53}$ One interviewee recommends paying particular attention to one's instincts: 
Read a little or talk to some folks that do it. But mostly ask yourself "what doesn't feel right in this class?" Take the time to reflect on what you and the students are feeling. Then work with them to do things differently, in ways that feel right. Go slow and just take one bite at a time.

Similarly, one individual felt it highly important to question assumptions as the foundation to one's critical practice:

Reading can help build comfort with critical information literacy, but a lack of familiarity with [the literature] should not prevent us from trying new approaches in the classroom. We as librarians need to challenge our own assumptions, as well as those of our students. Pausing to ask, "Why is this like this?" can help us and our students reflect on and deconstruct those assumptions.

Another librarian provided a specific reading recommendation that was transformational for her own work:

Read Maria Accardi's book on Feminist Pedagogy [Feminist Pedagogy for Library Instruction] ... her personal narrative really helped me see that this work is connected to one's personhood (thus, the emotional toll it takes). Realize that when you really care about something and it doesn't always pan out, it's difficult.

Several librarians offered useful pedagogical advice for those interested in critical library instruction. One's approach to working with students was mentioned most frequently, particularly in the sense of treating students as valued contributors: "CIL is scalable and very doable. Put down the script! Trust the intelligence of your students and be willing to learn alongside them." Another librarian advocates a strongly student-centered approach: "Talk to your students. Ask them what they care about. Listen to your students. Honor what they say, and take action in small ways that you can. Believe them and respect them as having experience, knowledge and significance." Finally, a participant noted the importance of curiosity, humanizing our interactions with library users, and how that should extend to all aspects of the library:

Be curious and let that curiosity be obvious in the classroom. I think a lot of the benefit of the critical approach is to humanize approaching, interacting and thinking about, in this case, info lit and/or library services. I do think that the critical approach should influence not only how info lit is being taught but also how library services are conceived, developed and rolled out.

Above all, the librarians who contributed to this study expressed an excitement about and commitment to critical IL while acknowledging the challenges of its everyday practice. "Building connections with instructors and with the curriculum takes time, and reshaping expectations can be frustrating work," one librarian summarizes, "but if the goal is to educate 'whole persons,' then library instruction needs to be part of that process in a meaningful way. Critical information literacy can provide that meaning." The excitement regarding this type of teaching was especially notable among librarians relatively new to the profession, with one participant noting an appreciation present in many others' comments: "It's really encouraging to be a new librarian and see this community taking off due to the hard work of so many." As one person succinctly states regarding critical IL: "It's pretty much the best thing that's ever happened to my teaching." 


\section{Acknowledgments}

The author expresses his profound thanks to everyone who contributed their ideas and thoughts to this project through participating in the survey and, in particular, to the thirteen interviewees who volunteered their time to respond to questions about themselves and their work with such thoughtfulness and care. The author also recognizes the extensive support provided by the Institute for Research Design in Librarianship and the many wonderful people involved in the program.

\section{APPENDIX A. Survey Instrument}

Q1: Are you currently employed by an academic library?
$\square \quad$ Yes
$\square \quad$ No
$\square \quad$ Other:

Q2: Do you provide instruction related to library and information resources and/or information literacy?
$\square \quad$ Yes
$\square \quad \mathrm{No}$
$\square \quad$ Unsure
口 Other:

Q3: How many years have you worked in a library of any type after receiving your MLS or its equivalent?
$\square \quad 0-4$ years
ㄴ 5-9 years
$\square \quad 10-14$ years
$\square \quad 15$ or more years
$\square \quad$ Unsure
$\square \quad$ Have not received an MLS
$\square$ Other:

Q4: Which best describes the type of institution at which you currently work?
$\square \quad$ Community College
$\square \quad$ University
$\square \quad$ College
$\square \quad$ Other:

Q5: What is the approximate number of students who attend your institution?
$\square \quad$ Fewer than 1,000
1,000-4,999
$\quad 5,000-9,999$
10,000-19,999
$\quad 20,000-29,999$
- $\quad 30,000$ or more
口 Unsure

Q6: Do you incorporate critical information literacy into your classroom instruction?
$\square \quad$ Yes
No
$\square \quad$ Unsure
$\square \quad$ Other (please specify): 
Q7: If you responded "yes" to the previous question, please provide one or two examples of how you do so.

Q8: Briefly describe some of the benefits to making critical information literacy part of your classroom instruction, if you find that there are benefits.

Q9: Briefly describe some of the challenges involved in making critical information literacy part of your classroom instruction, if you find that there are challenges.

Q10: Are there critical information literacy ideas or practices that you would like to incorporate into your classroom instruction but have not? If yes, please briefly describe them below.

Q11: What advice might you give to academic librarians who seek to make critical information literacy a part of their practice but are unsure how to do so?

Q12: Please include any additional comments you may have about the practice of critical information literacy below.

Q13: The author of this survey will be conducting interviews with selected survey respondents in January and February 2016. The questions will pertain to ways that interviewees incorporate critical information literacy into their instruction, as well as the benefits and challenges they experience in doing so. If you would like to be contacted about the possibility of doing an interview via telephone or e-mail, please enter your preferred e-mail address below. Thank you for considering.

\section{APPENDIX B. Interview Questions}

1. Tell me about how you first learned about critical information literacy.

2. Tell me about a time when you incorporated critical information literacy into a class you taught.

3. Do you find that critical information literacy is beneficial to your classroom instruction? If so, how?

4. Are there theoretical or conceptual understandings that inform your practice of critical information literacy? These could be theories, ideas, or writings related to education, social justice, libraries, or other areas meaningful to you or your work.

5. What are some of the specific classroom methods, if any, that you use in your practice of critical information literacy? These could be activities, search examples, class discussions, or other teaching methods.

6. Tell me about barriers you may have experienced making critical information literacy part of your practice.

7. What factors contribute positively to your practice of critical information literacy?

8. Is there anything you would like to add that we haven't yet discussed?

\section{Notes}

1. Allen Luke and Cushla Kapitzke, "Literacies and Libraries: Archives and Cybraries," Pedagogy, Culture \& Society 7, no. 3 (1999): 467-91.

2. Lua Gregory and Shana Higgins, Information Literacy and Social Justice: Radical Professional Praxis (Sacramento, Calif.: Library Juice Press, 2013).

3. David James Hudson, "The Whiteness of Practicality," in Topographies of Whiteness: Mapping Whiteness in Library and Information Studies (Sacramento, Calif.: Library Juice Press, 2017). 
4. Christine Pawley, "Information Literacy: A Contradictory Coupling," Library Quarterly 73, no. 4 (2003): 422-52.

5. Cushla Kapitzke, "Information Literacy: A Review and Post Structural Critique," Australian Journal of Language and Literacy 26, no. 1 (2003): 53.

6. Lisa O'Connor, "Information Literacy as Professional Legitimation: The Quest for a New Jurisdiction," Library Review 58, no. 7 (2009): 493-508.

7. Cathy Eisenhower and Dolsy Smith, "The Library as 'Stuck Place': Critical Pedagogy in the Corporate University," in Critical Library Instruction: Theories and Methods (Sacramento, Calif.: Library Juice Press, 2010): 305-18; John Buschman, Libraries, Classrooms, and the Interests of Democracy: Marking the Limits of Neoliberalism (Lanham, Md.: Scarecrow Press, 2012); Maura Seale, "The Neoliberal Library," in Information Literacy and Social Justice: Radical Professional Praxis (Sacramento, Calif.: Library Juice Press, 2013): 39-61; Jonathan Cope, "Neoliberalism and Library \& Information Science: Using Karl Polanyi's Fictitious Commodity as an Alternative to Neoliberal Conceptions of Information," Progressive Librarian, no. 43 (2014): 67-80; Karen P. Nicholson, "The McDonaldization of Academic Libraries and the Values of Transformational Change," College $\mathcal{E}$ Research Libraries 76, no. 3 (2015): 328-38.

8. Annie Downey, Critical Information Literacy: Foundations, Inspiration, and Ideas (Sacramento, Calif.: Library Juice Press, 2016), 33.

9. Eamon Tewell, "ADecade of Critical Information Literacy: A Review of the Literature," Communications in Information Literacy 9, no. 1 (2015): 24-43; Beth Allsopp McDonough, "Critical Information Literacy in Practice: An Interpretive Synthesis" (PhD diss., Western Carolina University, 2014).

10. McDonough, "Critical Information Literacy in Practice," 12.

11. James Elmborg, "Critical Information Literacy: Implications for Instructional Practice," Journal of Academic Librarianship 32, no. 2 (2006): 192-99.

12. Ibid., 192-93.

13. James Elmborg, "Critical Information Literacy: Definitions and Challenges," in Transforming Information Literacy Programs: Intersecting Frontiers of Self, Library Culture, and Campus Community (2012): 75-80.

14. Michelle Holschuh Simmons, "Librarians as Disciplinary Discourse Mediators: Using Genre Theory to Move toward Critical Information Literacy," portal: Libraries and the Academy 5, no. 3 (2005): 297-311.

15. Troy A. Swanson, "A Radical Step: Implementing a Critical Information Literacy Model," portal: Libraries and the Academy 4, no. 2 (2004): 259-73.

16. John J. Doherty, "No Shhing: Giving Voice to the Silenced: An Essay in Support of Critical Information Literacy," Library Philosophy and Practice 9, no. 2 (2007).

17. Critical Library Instruction: Theories and Methods, eds. Maria T. Accardi, Emily Drabinski, and Alana Kumbier (Sacramento, Calif.: Library Juice Press, 2010).

18. Information Literacy and Social Justice: Radical Professional Praxis, eds. Lua Gregory and Shana Higgins (Sacramento, Calif.: Library Juice Press, 2013); Informed Agitation: Library and Information Skills in Social Justice Movements and Beyond, ed. Melissa Morrone (Sacramento, Calif.: Library Juice Press, 2014); Robert Schroeder, Critical Journeys: How 14 Librarians Came to Embrace Critical Practice (Sacramento, Calif.: Library Juice Press, 2014).

19. Downey, Critical Information Literacy: Foundations, Inspiration, and Ideas.

20. Ian G. Beilin and Anne E. Leonard, "Teaching the Skills to Question: A Credit-Course Approach to Critical Information Literacy," Urban Library Journal 19, no. 1 (2013).

21. Scott Warren and Kim Duckett, "'Why Does Google Scholar Sometimes Ask for Money?' Engaging Science Students in Scholarly Communication and the Economics of Information," Journal of Library Administration 50, no. 4 (2010): 349-72; Alison Hicks, "Cultural Shifts: Putting Critical Information Literacy into Practice," Communications in Information Literacy 7, no. 1 (2013): 50-65; Heidi Jacobs, "Pedagogies of Possibility Within the Disciplines: Critical Information Literacy and Literatures in English," Communications in Information Literacy 8, no. 2 (2014): 192-207.

22. Lauren Smith, "Towards a Model of Critical Information Literacy Instruction for the Development of Political Agency," Journal of Information Literacy 7, no. 2 (2013): 15-32.

23. Sonja Spiranec, Mihaela Banek Zorica, and Denis Kos, "Information Literacy in Participatory Environments: The Turn Towards a Critical Literacy Perspective," Journal of Documentation 72, no. 2 (2016): 247-64.

24. Robert Schroeder and Christopher V. Hollister, "Librarians' Views on Critical Theories and Critical Practices," Behavioral \& Social Sciences Librarian 33, no. 2 (2014): 91-119.

25. Sanford Berman, Prejudices and Antipathies: A Tract on the LC Subject Heads Concerning People (Jefferson, N.C.: McFarland, 1993); Hope A. Olson, "The Power to Name: Representation in Library Catalogs," Signs 26, no. 3 (2001): 639-68; Radical Cataloging: Essays at the Front, ed. K.R. Roberto 
(Jefferson, N.C.: McFarland, 2008); Emily Drabinski, “Queering the Catalog: Queer Theory and the Politics of Correction," Library Quarterly 83, no. 2 (2013): 94-111.

26. Maria T. Accardi, Feminist Pedagogy for Library Instruction (Sacramento, Calif.: Library Juice Press, 2013).

27. Char Booth, “On Information Privilege," info-mational, published 1 December 2014 at https:// infomational.wordpress.com/2014/12/01/on-information-privilege [accessed 20 July 2016].

28. Safiya Umoja Noble, Algorithms of Oppression: How Search Engines Reinforce Racism (New York, N.Y.: New York University Press, 2018).

29. Amit Datta, Michael Carl Tschantz, and Anupam Datta, "Automated Experiments on Ad Privacy Settings," Proceedings on Privacy Enhancing Technologies 2015, no. 1 (2015): 92-112; Latanya Sweeney, "Discrimination in Online Ad Delivery," Communications of the ACM 56, no. 5 (2013): 44-54.

30. McDonough, "Critical Information Literacy in Practice," 89.

31. bell hooks, Teaching to Transgress: Education as the Practice of Freedom (New York, N.Y.: Routledge, 1994), 130.

32. Accardi, Feminist Pedagogy for Library Instruction, 58.

33. Downey, Critical Information Literacy: Foundations, Inspiration, and Ideas, 91.

34. McDonough, "Critical Information Literacy in Practice."

35. Pamela N. Martin, "Societal Transformation and Reference Services in the Academic Library: Theoretical Foundations for Re-envisioning Reference," Library Philosophy and Practice (2009): 5.

36. Downey, Critical Information Literacy: Foundations, Inspiration, and Ideas.

37. Joshua F. Beatty, "Reading Freire for First World Librarians," paper presented at the Canadian Association of Professional Academic Librarians conference, Ottawa, Ontario, Canada, June 2, 2015.

38. Emily Drabinski, "Toward a Kairos of Library Instruction," Journal of Academic Librarianship 40, no. 5 (2014): 480-85.

39. Simmons, "Librarians as Disciplinary Discourse Mediators," 308.

40. Heidi L.M. Jacobs, "Posing the Wikipedia 'Problem': Information Literacy and the Praxis of Problem-Posing in Library Instruction," in Critical Library Instruction: Theories and Methods (Sacramento, Calif.: Library Juice Press, 2010): 179-97.

41. Ian Beilin, "Student Success and the Neoliberal Academic Library," Canadian Journal of Academic Librarianship 1, no. 1 (2016): 17.

42. Downey, Critical Information Literacy: Foundations, Inspiration, and Ideas.

43. L.M. Jacobs, "Information Literacy and Reflective Pedagogical Praxis," Journal of Academic Librarianship 34, no. 3 (2008): 258.

44. Beilin, "Student Success and the Neoliberal Academic Library," 18.

45. Nicholson, "The McDonaldization of Academic Libraries," 333.

46. Jessica Critten, introduction to Annie Downey, Critical Information Literacy: Foundations, Inspirations, Ideas (Sacramento, Calif.: Library Juice Press, 2016), 6.

47. hooks, Teaching to Transgress, 87.

48. hooks, Teaching to Transgress.

49. bell hooks, Ain't I a Woman: Black Women and Feminism (New York, N.Y.: South End Press, 1981).

50. Critical Library Instruction Handbook, vol. 1 \& 2, eds. Nicole Pagowsky and Kelly McElroy (Chicago, Ill.: ACRL Press, 2016).

51. "Critlib: critical librarianship, in real life \& on the twitters," Critlib, available online at critlib.org [accessed 15 September 2016].

52. Schroeder, Critical Journeys, 2.

53. Heidi Jacobs, interview by Robert Schroeder, Critical Journeys, 156. 